\title{
Editorial
}

\section{Drugs from Marine Sources}

\author{
Carmela Gallo (D) and Genoveffa Nuzzo *(D)
}

check for updates

Citation: Gallo, C.; Nuzzo, G. Drugs from Marine Sources. Appl. Sci. 2021, 11, 12115. https://doi.org/10.3390/ app112412115

Received: 9 December 2021

Accepted: 14 December 2021

Published: 20 December 2021

Publisher's Note: MDPI stays neutral with regard to jurisdictional claims in published maps and institutional affiliations.

Copyright: () 2021 by the authors. Licensee MDPI, Basel, Switzerland. This article is an open access article distributed under the terms and conditions of the Creative Commons Attribution (CC BY) license (https:/ / creativecommons.org/licenses/by/ $4.0 /)$.
Bio-Organic Chemistry Unit, Institute of Biomolecular Chemistry, Consiglio Nazionale delle Ricerche, Via Campi Flegrei 34, 80078 Pozzuoli, Italy; carmen.gallo@icb.cnr.it

* Correspondence: nuzzo.genoveffa@icb.cnr.it

Throughout history, natural products have afforded a rich source of compounds that have found many applications in the fields of pharmacology. In this context, Marine Natural Products (MNPs) represent a unique rich source of new metabolites, with diverse chemical structures, and various bioactivities and molecular characteristics adapted to specific interactions with cellular targets. The huge diversity and potential bioactivity of marine metabolites can serve as "lead" compounds for the discovery of modern drugs. Thus, these products are attractive targets because they could be used to overcome the challenge of treating a high number of diseases that affect human health.

This Special Issue has covered all fields of drugs research from marine natural products, including their isolation and characterization, in vitro and/or in vivo study of their biological activities, medicinal applications as well as synthetic approaches and related analogues.

In detail, two studies are reported in this Special Issue on the chemical characterization and biological activity of alginate from two species of Sargassum; in particular, alginate was investigated for wound-healing and antioxidant properties on a diabetic mouse model $[1,2]$. A third work reports the bioactivity-guided study of Aquimarina sp. with the identification of diketopiperazines and N-Phenethylacetamide and their effect on TGF- $\beta$-induced epithelial-mesenchymal transition [3].

Pharmacokinetic and drug metabolism tests are mandatory for expediting the progress of compounds with promising properties from discovery to development phase. For this purpose, a further manuscript is included about the investigation of a robust and fast analytical method for the measurement of Sulfavant A, a prototype for a new class of molecular adjuvants inspired by natural $\alpha$-sulfoquinovosyl-diacylglycerols ( $\alpha$-SQDGs) occurring in diatoms by Ultra High Performance Liquid Chromatography coupled with High Resolution Mass Spectrometry (UHPLC-HRMS) [4].

As part of this Special Issue, two reviews about medicinal applications of natural products from marine sources have been reported. In particular a minireview details the potential applications of diatom-derived silica for the biomedical field [5]; finally, a review describes the advances in purpurin 18 research as a promising anticancer drug [6].

Author Contributions: Conceptualization, G.N.; review papers and writing editorial, C.G. and G.N All authors have read and agreed to the published version of the manuscript.

Funding: This work was supported by the project "Antitumor Drugs and Vaccines from the Sea (ADViSE)” project (CUP B43D18000240007-SURF 17061BP000000011) funded by POR Campania FESR 2014-2020 “Technology Platformfor Therapeutic Strategies against Cancer"-Action 1.1.2 and 1.2.2.

Conflicts of Interest: The authors declare no conflict of interest. 


\section{References}

1. Pudjiastuti, P. Characterization of Alginate from Sargassum duplicatum and the Antioxidant Effect of Alginate-Okra Fruit Extracts Combination for Wound Healing on Diabetic Mice. Appl. Sci. 2020, 10, 6082.

2. Wulandari, P.A.C.; Ilmi, Z.N.; Husen, S.A.; Winarni, D.; Alamsjah, M.A.; Awang, K.; Vastano, M.; Pellis, A.; MacQuarrie, D.; Pudjiastuti, P. Wound Healing and Antioxidant Evaluations of Alginate from Sargassum ilicifolium and Mangosteen Rind Combination Extracts on Diabetic Mice Model. Appl. Sci. 2021, 11, 4651. [CrossRef]

3. Lee, M.J.; Kim, G.J.; Shin, M.-S.; Moon, J.; Kim, S.; Nam, J.-W.; Kang, K.S.; Choi, H. Chemical Investigation of Diketopiperazines and N-Phenethylacetamide Isolated from Aquimarina sp. MC085 and Their Effect on TGF- $\beta$-Induced Epithelial-Mesenchymal Transition. Appl. Sci. 2021, 11, 8866. [CrossRef]

4. Nuzzo, G.; Manzo, E.; Ziaco, M.; Fioretto, L.; Campos, A.M.; Gallo, C.; D’Ippolito, G.; Fontana, A. UHPLC-MS Method for the Analysis of the Molecular Adjuvant Sulfavant A. Appl. Sci. 2021, 11, 1451. [CrossRef]

5. Sardo, A.; Orefice, I.; Balzano, S.; Barra, L.; Romano, G. Mini-Review: Potential of Diatom-Derived Silica for Biomedical Applications. Appl. Sci. 2021, 11, 4533. [CrossRef]

6. Pavlíčková, V.; Škubník, J.; Jurášek, M.; Rimpelová, S. Advances in Purpurin 18 Research: On Cancer Therapy. Appl. Sci. 2021, 11, 2254. [CrossRef] 